\title{
ANALISIS KESALAHAN MAHASISWA PGSD DALAM MENYELESAIKAN MASALAH GEOMETRI
}

\author{
A. Wilda Indra Nanna ${ }^{1}$, Enditiyas Pratiwi ${ }^{2}$, Cahyo Anggraeni ${ }^{3}$ \\ ${ }^{1,2}$ Program Studi Pendidikan Guru Sekolah Dasar, Universitas Borneo Tarakan \\ Email: wiradjab@gmail.com
}

\begin{abstract}
Abstrak:
Salah satu mata kuliah yang dianggap sulit oleh mahasiswa PGSD adalah mata kuliah Geometri, terbukti dengan hanya $10 \%$ mahasiswa yang mencapai hasil belajar kategori sangat baik dan baik. Kesulitan yang dialami mahasiswa menyebabkan terjadinya kesalahan dalam menyelesaikan masalah geometri. Kesalahan yang terjadi ketika mahasiswa menyelesaikan masalah geometri sangat perlu untuk diketahui, terutama jenis kesalahannya. Salah satu prosedur yang dapat digunakan untuk mengungkapkan kesalahan mahasiswa tersebut adalah prosedur Newman. Penelitian ini merupakan penelitian deskriptif kualitatif yang bertujuan untuk menganalisis kesalahan mahasiswa PGSD dalam menyelesaikan masalah geometri. Partisipan dalam penelitian ini adalah dua mahasiswa PGSD yang telah menempuh mata kuliah Geometri dan memenuhi kriteria dalam penelitian, yaitu mengalami kesalahan matematis. Teknik pengumpulan data menggunakan tes uraian dan wawancara. Pemberian tes uraian dilakukan untuk menganalisis kesalahan mahasiswa dalam menyelesaikan masalah geometri. Sedangkan wawancara dilakukan untuk mengkonfirmasi hasil pekerjaan mahasiswa. Berdasarkan hasil penelitian dapat disimpulkan bahwa partisipan mengalami kesalahan pada empat tahapan prosedur Newman yaitu pemahaman, transformasi, keterampilan proses dan encoding. Kesalahan yang muncul adalah kesalahan matematis, logis dan strategis. Kemudian, sebagai temuan baru dalam penelitian ini, kesalahan yang dialami oleh mahasiswa pada tahapan prosedur Newman dapat menyebabkan kesalahan pada tahapan selanjutnya.
\end{abstract}

Kata Kunci: Kesalahan, Geometri, Pemecahan Masalah, Newman, Mahasiswa

\begin{abstract}
:
One of the subjects considered difficult by PGSD students is the Geometry course, as evidenced by only $10 \%$ of students who achieved excellent and good category learning outcomes. The difficulties experienced by students cause errors in solving geometric problems. Errors that occur when students solve geometry problems need to be known, especially the types of errors. One of the procedures that can be used to reveal student errors is the Newman procedure. This research is a qualitative descriptive study that aims to analyze the mistakes of PGSD students in solving geometry problems. Participants in this study were two PGSD students who had taken the Geometry course and met the criteria in the study, namely experiencing mathematical errors. Data collection techniques using test descriptions and interviews. Giving test descriptions is done to analyze student errors in solving geometry problems. Meanwhile, interviews were conducted to confirm the results of student work. Based on the research results, it can be concluded that the participants experienced errors in the four stages of the Newman procedure, namely understanding, transformation, processing skills and encoding. The errors that arise are mathematical, logical and strategic mistakes. Then, as a new finding in this study, errors experienced by students at the Newman procedure stage can lead to errors at later stages.
\end{abstract}

Keywords: Error, Geometry, Problem-Solving, Newman, Students

\section{Pendahuluan}

Pemecahan masalah adalah kondisi

di mana siswa diberikan tugas yang solusinya belum diketahui sehingga pengembangan pemahaman matematika

yang baru dapat terbentuk melalui
pemanfaatan pengetahuan mereka
("National Council of Teachers of
Mathematics," 2008). Kegiatan belajar
matematika tidak terlepas dari masalah


matematika. Belajar matematika akan berkembang dari pemahaman matematika dan strategi apa yang digunakan dalam menyelesaikan masalah matematika. Untuk pengajaran yang efektif, seorang pengajar perlu mempertimbangkan pengetahuan dan keterampilan mahasiswa seperti pengetahuan sebelumnya, kemampuan pemecahan masalah dan keterampilan matematis lainnya. Pendekatan pemecahan masalah muncul dalam semua upaya manusia dalam kegiatan matematika. Upaya dalam mendefinisikan masalah dan mencari cara berbeda untuk menyelesaikannya adalah pusat pengembangan disiplin ilmu (Santos-Trigo, 2020).

Ketika mahasiswa menyelesaikan masalah matematika, maka sangat memungkinkan melakukan kesalahankesalahan dalam proses pemecahan masalahnya. Hasil penelitian (Avcu \& Avcu, 2010) menunjukkan mahasiswa calon guru sekolah dasar memiliki kemampuan untuk menggunakan strategi pemecahan masalah dan memecahkan masalah namun penggunaan strategi yang berbeda sangat terbatas, meskipun demikian, sebagian besar tidak dapat menyelesaikan masalah dengan benar Hasil penelitian lainnya menunjukkan tidak semua peserta didik mampu memahami dan menerapkan konsep untuk memecahkan masalah, konsep matematika yang abstrak merupakan salah satu penyebab kesalahan dalam pemecahan masalah (Sulistyorini, 2018).

Kesalahan tidak dapat dihindari peserta didik dalam belajar matematika, termasuk dalam pemecahan masalah. Pengajar harus memberikan kesempatan bagi peserta didik untuk mencerminkan dan memperbaiki kesalahan, jawaban yang salah yang diberikan belum tentu dari proses berpikir yang salah (Sulistyorini, 2018). Pengajar perlu membuat analisis kesalahan yang paling banyak dialami oleh siswa (Haryanti et al., 2019). Kesalahan yang terjadi harus disadari oleh pengajar selama proses pembelajaran sehingga tindakan alternatif dapat segera diambil (Salleh et al., 2013).

Proses berpikir seseorang dalam menyelesaikan sebuah masalah tidak bisa ditebak maka diperlukan sebuah cara untuk menggalinya. Analisis kesalahan Newman (NEA) merupakan salah satu cara yang bisa digunakan oleh pengajar untuk mencari tahu penyebab mahasiswa melakukan kesalahan pada strategi pemecahan masalah yang mereka lakukan. Ketika seseorang berusaha menjawab pertanyaan matematika tertulis, maka orang tersebut harus melewati sejumlah rintangan berturut-turut: membaca, memahami, transformasi, keterampilan proses, dan encoding. Sementara itu, sepanjang penyelesaian selalu mungkin melakukan kesalahan ceroboh (Newman, 1977). (Prakitipong \& Nakamura, 2006) menambahkan bahwa sebelum siswa melanjutkan proses pemecahan masalah ke dalam prosedur matematis (perhitungan) harus dapat menafsirkan maksud dari pertanyaan masalah ke dalam konteks matematika yang sesuai sehingga dapat menjawab masalah dengan benar. Pembelajaran yang memungkinkan siswa untuk menafsirkan dan menganalisis kehidupan sehari-hari yang dapat diterapkan dalam bidang matematika, contohnya pada geometri (Özerem, 2012).

Geometri adalah bidang dalam matematika yang memberikan informasi tentang keterampilan berpikir spasial siswa (Ozkan \& Bal, 2017). Banyak siswa tidak memiliki pengetahuan tentang bentuk geometris dan sifat-sifatnya sehingga kesalahan sesekali terjadi pada siswa (Zilkova et al., 2015). Geometri tidak hanya mengembangkan kemampuan kognitif siswa, tetapi juga membentuk pemikiran konkret menjadi abstrak. Oleh karena itu, dalam mempelajari geometri yang merupakan salah satu bidang dalam matematika yang dapat memberikan informasi tentang kemampuan berpikir spasial siswa yang memungkinkan untuk menafsirkan dan menganalisis bentuk geometri dan sifat-sifatnya yang sering terjadi pada kesalahan siswa dalam geometri.

Geometri adalah salah satu materi yang sulit bagi siswa. Siswa harus memiliki kemampuan untuk memvisualisasikan, menggambarkan gambar, menggambar bentuk, dan mengenal bentuk 
(Nurhikmayati, 2017; Riastuti et al., 2017). Namun, kemampuan siswa maupun mahasiswa masih rendah.

Mahasiswa PGSD menganggap Geometri merupakan salah satu mata kuliah yang sulit dan juga terlihat dari hasil belajar yang masih rendah terbukti dengan hanya $10 \%$ mahasiswa yang mencapai hasil belajar kategori sangat baik dan baik. Mereka kesulitan dalam menyelesaikan soal-soal berbentuk masalah matematika yang lebih kompleks. Salah satu materi yang mempunyai tingkat kesulitan dan keabstrakan yang tinggi adalah materi dimensi tiga (bangun ruang). Sementara, geometri merupakan salah satu topik yang paling berlaku untuk kehidupan sehari-hari, namun sering menjadi topik yang diabaikan dalam kurikulum (Aslan-tutak \& Adams, 2015). Penelitian yang berfokus pada pengetahuan tentang geometri dalam pengajaran masih terbatas, selain itu mahasiswa sebagai calon guru tidak dilengkapi dengan konten yang diperlukan dan pengetahuan konten pedagogis dari geometri sehingga penting untuk mengatasi masalah ini dalam pendidikan guru (Browning et al., 2014; Hourigan \& Leavy, 2017; Jones, 2000).

Prosedur Newman sangat berguna untuk memeriksa keterampilan pemecahan masalah siswa. Prosedur Newman adalah metode yang menganalisis kesalahan sambil menyelesaikan masalah kalimat (Jha, 2012). Dari pemikiran tersebut, penelitian ini bertujuan untuk menganalisis kesalahan mahasiswa PGSD dalam menyelesaikan masalah geometri dengan menggunakan prosedur Newman. (Rohmah \& Sutiarso, 2018) menyatakan bahwa dengan mendiagnosis tingkat kesalahan siswa secara berkelanjutan dianggap akan menghasilkan peningkatan kinerja siswa dalam jangka panjang. Selain itu, faktor yang menyebabkan siswa mengalami kesalahan dalam menyelesaikan masalah matematika adalah tidak menyerap informasi dengan baik, tidak memahami transformasi masalah, tidak mengikuti materi secara menyeluruh, dan pemahaman konsep matematika lema. Pencegahan kesalahan perlu dilakukan karena akan berakibat fatal pada kesalahan materi lain (Safriani et al., 2019). (White, 2005) juga menyatakan bahwa kesalahan bisa menjadi mengakar, sehingga analisis kesalahan adalah langkah pertama untuk melakukan sesuatu yang relevan yang akan berguna dalam memberikan informasi penyebab terjadinya kesalahan.

\section{Metode Penelitian}

Penelitian ini menggunakan desain penelitian kualitatif yang bertujuan untuk menganalisis kesalahan mahasiswa PGSD Universitas Borneo Tarakan dalam menyelesaikan masalah geometri. Analisis kesalahan dalam penelitian ini menggunakan NEA (Newman Error Analysis) yang terdiri dari 5 tahap yaitu (1) membaca; (2) pemahaman; (3) transformasi; (4) keterampilan proses; dan (5) encoding. Calon partisipan dalam penelitian ini berjumlah 36 mahasiswa semester IV program studi PGSD Universitas Borneo Tarakan. Pemilihan calon partisipan didasarkan pada mahasiswa yang telah memprogram mata kuliah Geometri. Penelitian ini dilaksanakan pada Juni 2020.

Teknik pengumpulan data dalam penelitian ini adalah tes uraian dan wawancara. Tabel 1 berikut adalah pertanyaan yang digunakan untuk melihat letak kesalahan calon partisipan yang digunakan dalam proses wawancara.

Tabel 1. Rubrik Wawancara

\begin{tabular}{|c|c|}
\hline Tahapan & Pertanyaan \\
\hline Membaca & $\begin{array}{l}\text { Baca pertanyaannya. Jika tidak tahu maksud pada kalimatnya, } \\
\text { sampaikan kepada saya! }\end{array}$ \\
\hline Pemahaman & $\begin{array}{l}\text { Apa maksud dari pertanyaan tersebut dan jelaskan apa yang } \\
\text { kamu lakukan untuk menyelesaikan masalah ini! }\end{array}$ \\
\hline Transformasi & $\begin{array}{l}\text { Cara apa yang kamu gunakan untuk menyelesaikan masalah } \\
\text { tersebut? }\end{array}$ \\
\hline
\end{tabular}




\begin{tabular}{ll}
\hline Keterampilan Proses & Sekarang, lanjutkan semua langkah penyelesaian kamu dan \\
& jelaskan apa yang kamu pikirkan! \\
Encoding & Apa jawaban dari pertanyaan ini? \\
\hline
\end{tabular}

Tes uraian berjumlah 3 nomor diberikan kepada semua calon partisipan penelitian. Adapun instrumen soal yang digunakan dalam penelitian ini sebagai berikut:

1. Sebuah bak mandi berbentuk balok berukuran $70 \mathrm{~cm}$ x $60 \mathrm{~cm} \times 80 \mathrm{~cm}$. Bak telah berisi air sebanyak 22 liter. Ibu memenuhi bak tersebut dengan ember bervolume 12,56 liter. Berapa kali Ibu mengisi bak tersebut dengan ember sampai penuh?

2. Ayah akan memasang wallpaper pada studio foto miliknya dengan ukuran panjang $6 \mathrm{~m}$, lebar $3 \mathrm{~m}$, dan tinggi $3 \mathrm{~m}$. Satu rol wallpaper yang akan dibeli ayah berukuran $10 \mathrm{~m}$ x $45 \mathrm{~cm}$ dengan harga Rp45.000,00. Berapakah uang yang harus disiapkan ayah untuk membeli wallpaper jika hanya 3 dinding studio yang akan dipasangi?

3. Ibu mempunyai sebuah kaleng dengan jari-jari $14 \mathrm{~cm}$ dan tinggi $30 \mathrm{~cm}$. Kaleng tersebut akan digunakan untuk menyimpan gula aren berbentuk tabung dengan ukuran jari-jari $7 \mathrm{~cm}$ dan tinggi $6 \mathrm{~cm}$. Gambar di bawah ini merupakan kaleng dan gula aren ibu.
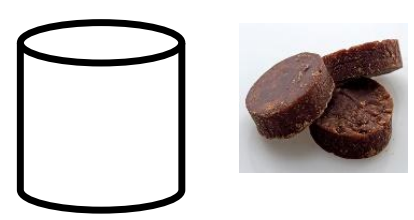

Berapakah gula aren utuh maksimal yang dapat disusun ibu dengan rapi ke dalam kaleng tersebut?

Berdasarkan hasil tes dilakukan analisis untuk menentukan calon partisipan yang diambil menjadi partisipan sebelum dilakukan wawancara semi terstruktur mendalam. Pengambilan partisipan mengacu pada kesalahan calon partisipan dalam menyelesaikan tes yang diberikan. Kesalahan yang dimaksud dalam penelitian adalah kesalahan matematis. Tabel 2 berikut memberikan klasifikasi kesalahan matematis yang dimaksud dalam penelitian ini.

Tabel 2. Klasifikasi Kesalahan Matematis

\begin{tabular}{ll} 
Matematis & $\begin{array}{l}\text { Bingung konsep, kelalaian dalam formula, } \\
\text { ataupun kondisi matematis }\end{array}$ \\
\hline Logis & $\begin{array}{l}\text { Argumen yang disampaikan salah, mengatur } \\
\text { ulang konsep, klasifikasi yang tidak sesuai, } \\
\text { mengulang-ulang pertanyaan yang sama }\end{array}$ \\
\hline Strategis & $\begin{array}{l}\text { Tidak menemukan cara/pola yang berbeda, } \\
\text { tidak dapat mengubah masalah }\end{array}$ \\
\hline Psikologis & Ketidaksiapan dalam menyelesaiakan masalah. \\
\hline
\end{tabular}

(Peng \& Luo, 2009)

Terdapat 2 calon partisipan yang terpilih menjadi partisipan karena memenuhi kriteria yang digunakan yaitu mengalami kesalahan matematis pada lembar kerja. Data utama dalam penelitian ini adalah hasil tes partisipan dan akan dilakukan proses triangulasi melalui wawancara semi terstruktur mendalam untuk mengetahui lebih jauh terkait kesalahan dalam proses pemecahan masalah. Teknik analisis data menggunakan model interaktif (Huberman \& Miles, 2012). Analisis terdiri dari tiga tahap kegiatan yang dapat dilakukan secara bersamaan yaitu reduksi data, penyajian data dan penarikan kesimpulan (verifikasi). 



\section{Hasil dan Pembahasan \\ Hasil \\ Analisis Prosedur Newman pada Partisipan A}

Bagian ini akan dijelaskan hasil analisis lembar jawaban partisipan yang dikonfirmasi melalui proses wawancara terkait jenis-jenis kesalahan yang dialami oleh partisipan dalam menyelesaikan masalah geometri.

Gambar 1 berikut adalah hasil jawaban partisipan A dalam menyelesaikan masalah

no.

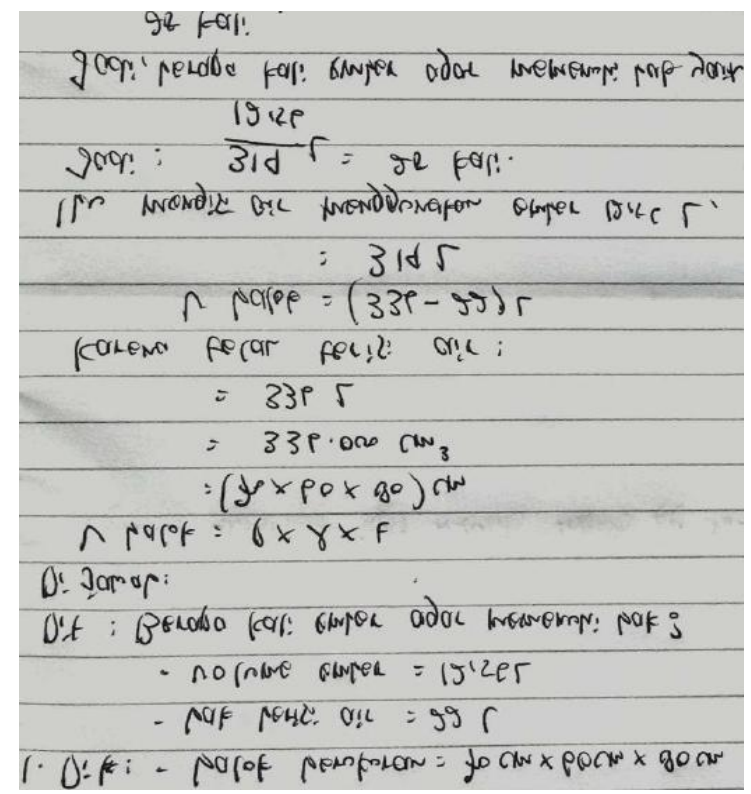

\section{Gambar 1. Jawaban Partisipan A}

Berdasarkan hasil analisis lembar kerja, partisipan A menjawab masalah pertama dengan benar dan tidak melakukan kesalahan melalui tahapan berikut:

a. Menentukan diketahui dan ditanyakan.

b. Menyusun rencana penyelesaian masalah dengan menggunakan volume balok. c. Menyelesaikan rencana yang telah disusun dengan lengkap sampai pada jawaban akhir yang diinginkan dengan cara membagi air yang diisi sampai bak mandi penuh dan isi air pada ember.

Hal tersebut kemudian dikonfirmasi melalui wawancara yang disajikan pada Tabel 3 berikut.

Tabel 3. Konfirmasi Jawaban Partisipan A pada Masalah Pertama

\begin{tabular}{lrl}
\hline \multicolumn{1}{c}{ Peneliti } & \multicolumn{1}{c}{ Partisipan A } \\
\hline $\begin{array}{l}\text { Silakan baca soal dan } \\
\text { sampaikan jika ada hal yang } \\
\text { tidak kamu ketahui! }\end{array}$ & \\
$\begin{array}{l}\text { Apakah kamu paham dengan } \\
\text { masalah pada nomor 1? }\end{array}$ & Ya, Bu. \\
$\begin{array}{l}\text { Bagaimana } \\
\text { penyelesaiannya? }\end{array}$ & cara & $\begin{array}{l}\text { Pertama mencari volume balok dengan menggunakan rumus } \\
\text { p x 1 x t, informasi ukuran balok sudah ada pada soal }\end{array}$ \\
& $\begin{array}{l}\text { sehingga diperoleh volume balok 336.000 } \mathrm{cm}^{3} \text {, karena } \\
\text { volumenya liter maka dikonversi menjadi 336 liter. Bak }\end{array}$ \\
& $\begin{array}{l}\text { sudah terisi air 22 liter, sehingga untuk mencari banyak air } \\
\text { yang diisi oleh ibu dengan cara mengurangi volume } \\
\text { keseluruhan balok dan volume air yang sudah terisi } \\
\text { sebelumnya. Selanjutnya volume yang didapatkan yaitu } 314\end{array}$
\end{tabular}


liter dibagi dengan volume ember 12, 56 liter dan menghasilkan jawaban 25. Sehingga bisa disimpulkan ibu mengisi bak mandi sebanyak 25 kali dengan ember hingga terisi penuh.

Kamu yakin dengan Yakin, Bu. Karena sudah memasukkan semua informasi jawabannya? yang ada pada soal dan saya sudah menggunakan rumusnya.

Partisipan A meyakini tidak melakukan kesalahan dalam penyelesaian masalah yang dikerjakan pada masalah pertama. Hal tersebut juga dapat dilihat pada Gambar 1 yang menunjukkan jawaban partisipan A benar. Dari hasil wawancara, terlihat pada tahapan membaca partisipan tidak mengalami kesalahan, pada tahapan pemahaman, transformasi, keterampilan proses dan encoding juga tidak mengalami kesalahan. Partisipan A menunjukkan pemahaman dan mampu menjelaskan semua proses yang dilalui selama menyelesaikan masalah. Partisipan A memenuhi semua langkah-langkah yang dilalui dalam memecahkan masalah berdasarkan prosedur Newman.

Jawaban partisipan A dalam menyelesaikan masalah kedua dapat dilihat pada Gambar

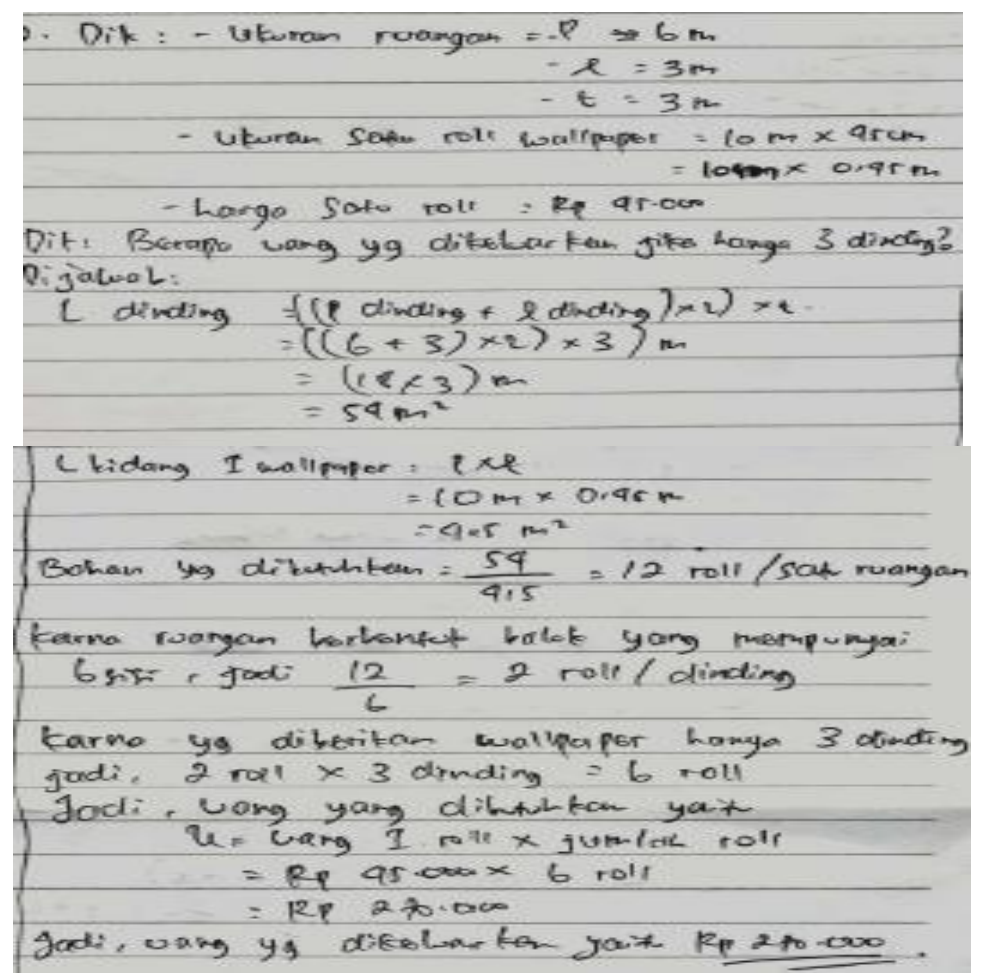

\section{Gambar 2. Jawaban Partisipan A}

Berdasarkan hasil analisis lembar kerja, partisipan A menjawab masalah kedua melalui tahapan berikut:

a. Menuliskan informasi diketahui dan ditanyakan.

b. Memahami langkah-langkah untuk sampai pada jawaban akhir tetapi mengalami bingung konsep dalam menggunakan luas dinding sebagai rencana penyelesaian. c. Untuk wallpaper, partisipan A menggunakan rumus luas persegi panjang. Partisipan A tidak bisa menemukan hubungan antara luas dinding dan luas wallpaper.

d. Menghitung jumlah uang yang dibutuhkan dengan melanjutkan rencana penyelesaian yang telah disusun. Karena sudah mengalami 
kebingungan dalam konsep sehingga

formula yang digunakan salah.
Hal tersebut kemudian dikonfirmasi melalui wawancara yang disajikan pada Tabel

Tabel 4. Konfirmasi Jawaban Partisipan A pada Masalah Kedua

\begin{tabular}{|c|c|}
\hline Peneliti & Partisipan A \\
\hline Silakan baca soal kedua! & (membaca soal) \\
\hline $\begin{array}{l}\text { Apa kamu paham dengan } \\
\text { maksud soal ini? }\end{array}$ & $\begin{array}{l}\text { Soal ini ditanyakan uang yang harus disediakan ayah } \\
\text { jika wallpaper yang akan dipasang hanya pada } 3 \text { dinding } \\
\text { saja. }\end{array}$ \\
\hline $\begin{array}{l}\text { Bagaimana cara kamu } \\
\text { menyelesaikan masalah ini? }\end{array}$ & $\begin{array}{l}\text { Luas dinding dicari dengan cara luas persegi panjang } \\
\text { dikali dengan tinggi dari lantai ke plafon hasilnya } 54 \mathrm{~m}^{2} \text {. } \\
\text { Untuk mencari luas wallpaper menggunakan rumus luas } \\
\text { persegi panjang jadi luas satu wallpaper adalah } 4,5 \mathrm{~m}^{2} \text {. } \\
\text { Setelah itu } 54: 4,5=12 \text { rol wallpaper. Karena ruangan } \\
\text { berbentuk balok yang mempunyai } 6 \text { sisi jadi } 12 \text { roll : } 6 \text {, } \\
\text { satu dinding membutuhkan } 2 \text { wallpaper. Ayah hanya } \\
\text { akan memasang pada } 3 \text { dinding sehingga } 3 \text { x } 2=6 \\
\text { wallpaper. Jumlah wallpaper dikalikan dengan } \\
\text { Rp45.000,00, jadi total uang Rp270.000,00. }\end{array}$ \\
\hline $\begin{array}{l}\text { Kamu yakin } \\
\text { jawabannya? }\end{array}$ & $\begin{array}{l}\text { Yakin, Bu. Karena saya sudah menuliskan semua } \\
\text { informasi yang ada pada diketahui dan ditanyakan. }\end{array}$ \\
\hline $\begin{array}{l}\text { Cara yang kamu gunakan untuk } \\
\text { menghitung luas dinding apa } \\
\text { sudah benar? }\end{array}$ & $\begin{array}{l}\text { Iya, Bu. Karena cara mencari luas adalah luas persegi } \\
\text { panjang dikali tinggi dari lantai ke plafon. }\end{array}$ \\
\hline Bisa divisualisasikan prosesnya? & $\begin{array}{l}\text { (menggambar persegi panjang) } \\
\text { kan ini dinding, terus ini ada lantai sama plafon jadi } \\
\text { tinggi itu terpisah dengan dinding. }\end{array}$ \\
\hline $\begin{array}{l}\text { Luas dinding sama dengan } \\
\text { wallpaper? }\end{array}$ & $\begin{array}{l}\text { Beda, Bu. Kalau dinding itu ada tingginya tapi kalo } \\
\text { wallpaper tidak ada, Bu. Tingginya itu dari lantai } \\
\text { sampai plafon. }\end{array}$ \\
\hline $\begin{array}{l}\text { Bisa kamu tunjukkan panjang } \\
\text { dan lebar dari dinding? }\end{array}$ & (menunjukkan panjang dan lebar pada kertas) \\
\hline $\begin{array}{l}\text { Bagaimana dengan bidang } \\
\text { wallpaper? }\end{array}$ & (hmmmm, agak ragu) persegi panjang \\
\hline $\begin{array}{l}\text { Kemudian apa perbedaan antara } \\
\text { luas dinding dan wallpaper? }\end{array}$ & $\begin{array}{l}\text { Saya bingung, Bu. Kalau wallpaper hanya panjang dan } \\
\text { lebar tapi kalo dinding itu menempel dengan lantai dan } \\
\text { plafon jadi ada tinggi. }\end{array}$ \\
\hline $\begin{array}{l}\text { Jadi tetap luas dinding itu } \\
\text { menggunakan tinggi? }\end{array}$ & Iya, Bu. Tetap. \\
\hline
\end{tabular}

Pada masalah kedua, partisipan A hanya benar pada tahapan membaca sedangkan mengalami beberapa kesalahan pada tahapan lainnya. Pada tahapan pemahaman, partisipan A mampu mendeskripsikan apa yang harus dilakukan untuk sampai pada jawaban akhir. Pada tahapan transformasi, partisipan A mengalami jenis kesalahan matematis yaitu bingung dalam konsep dan kelalaian dalam menggunakan formula karena tidak mampu melihat hubungan antara luas dinding dan luas wallpaper. Pada tahapan keterampilan proses, partisipan A mengalami jenis kesalahan logis dengan menggunakan argumen yang salah dalam pengambilan keputusan terkait cara yang digunakan untuk menghitung luas dinding. Partisipan A menginterpretasikan bahwa semua dinding memiliki tinggi, sehingga untuk 
menentukan luas persegi panjang adalah $\mathrm{p} \mathrm{x}$ $1 \mathrm{x}$ t. Akibat dari kesalahan pada tahapan sebelumnya sehingga partisipan A tidak bisa menyelesaikan pada tahapan encoding. Dalam proses wawancara, partisipan A diberikan scaffolding tetapi belum mampu menyelesaikan dan tetap meyakini bahwa luas dinding menggunakan tinggi.

Jawaban partisipan A dalam menyelesaikan masalah ketiga dapat dilihat pada Gambar

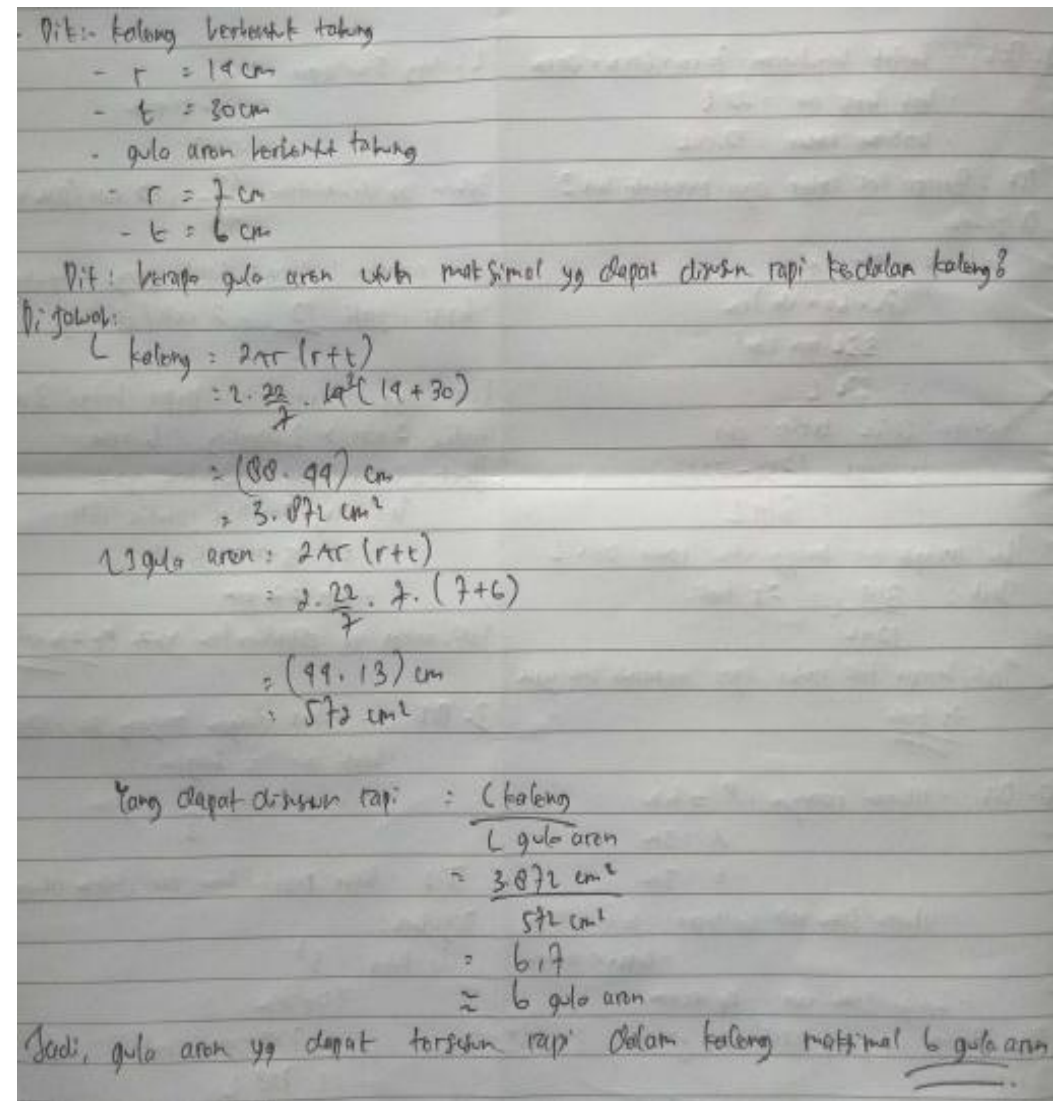

Gambar 3. Jawaban Partisipan A

Berdasarkan analisis hasil lembar kerja, partisipan A menjawab masalah ketiga melalui tahapan berikut:

a. Menuliskan informasi secara lengkap

b. Menggunakan luas permukaan tabung untuk menyelesaikan masalah. Partisipan A mengalami kelalaian dalam menentukan formula yang digunakan.

c. Membagi luas kaleng dengan luas gula aren untuk menentukan banyaknya gula aren yang dapat diisi.

Hal tersebut kemudian dikonfirmasi melalui wawancara yang disajikan pada Tabel

\section{5.}

Tabel 5. Konfirmasi Jawaban Partisipan A pada Masalah Ketiga

\begin{tabular}{ll}
\hline \multicolumn{1}{c}{ Peneliti } & \multicolumn{1}{c}{ Partisipan A } \\
\hline Silakan baca soalnya! & (membaca soal) \\
Bagaimana cara kamu & Caranya dengan mencari luas permukaan kaleng dan luas \\
menyelesaikan masalah ini? & permukaan gula aren yang berbentuk tabung. Luas kaleng \\
& $3.872 \mathrm{~cm}^{2}$ dan luas gula aren $572 \mathrm{~cm}^{2}$, lalu membagi luas \\
& permukaan kaleng dan luas permukaan gula aren hasilnya \\
& 6,7, karena gula arennya utuh maka dibulatkan 6, yang \\
& dapat disusun maksimal 6. \\
Perhatikan konteks soal, apa & Awalnya menggunakan rumus volume, tapi isi gula aren
\end{tabular}


kamu sudah yakin dengan jawabanmu?

Apa beda luas dan volume tabung? Bisa divisualisasikan?

Jika kamu tidak ingat rumus volume atau luas tabung, bisa bayangkan dengan hanya memperhatikan ukurannya?

Yakin yang mana?

Jika lupa rumus dan operasi hitung, apa yang kamu lakukan?

Sudah maksimal?

Perhatikan

ukurannya!

Maksudnya?

Sudah yakin? terlalu banyak. Sementara tinggi kaleng dan gula aren hanya $30 \mathrm{~cm}$ dan $7 \mathrm{~cm}$. Pada saat mengerjakan saya berpikir volume itu harus liter jadi bingung tapi harusnya ini volume.

(Diam sejenak dan berpikir)

(mengambil gelas dan menunjukkan luas dan volume)

Volume itu yang di dalam, luas permukaan di luar.

Jari-jari dikali dengan 30, 14 x 30 hasilnya 420. Kemudian untuk gula 7 x 6=42, lalu dibagi hasilnya 10 .

Yakin luas permukaan karena sudah tahu rumusnya, sedangkan tadi hanya mengalikan angka.

(Diam). Karena tinggi kaleng $30 \mathrm{~cm}$, jika gula aren dimasukkan 1 buah dengan tinggi $6 \mathrm{~cm}, 30$ - 6, sampai penuh dapat 5

Iya, Bu.

kembali Sepertinya belum masih ada sisa sedikit tapi itu pun miring.

Gula aren dipotong setengah jadi ada $5 \frac{1}{2}$.

(berpikir) kan jari-jari kaleng 14, terus jari-jari gula aren itu 7 jadi harusnya ada 2 , sebelahnya 5 itu masih ada 5 lagi. Hmmm, jawabannya 10 gula aren.
Berdasarkan hasil tes dan wawancara dengan partisipan A, ditemukan kesalahan-kesalahan yang muncul selain yang ditemukan pada hasil lembar kerja, yaitu kesalahan matematis (kelalaian dalam formula). Pada tahapan pemahaman, terjadi kesalahan matematis yaitu bingung konsep antara volume dan luas permukaan bangun. Pada tahapan transformasi, juga mengalami jenis kesalahan matematis yaitu kelalaian dalam menggunakan formula. Selain itu, jenis kesalahan logis juga terjadi di mana partisipan A, yaitu mengatur ulang konsep. Pada awalnya, partisipan A menggunakan konsep volume tabung untuk menyelesaikan masalah ketiga. Namun, hasil perhitungan dengan menggunakan formula volume tabung dianggap menghasilkan bilangan yang besar. Menurut partisipan A, bilangan besar tersebut tidak mungkin. Sehingga partisipan A mengubah formula yang digunakan. Dengan melakukan perbandingan tinggi kaleng dan tinggi gula aren, partisipan A memutuskan untuk menggunakan luas permukaan untuk yang menghasilkan bilangan kecil. Selain itu, satuan volume tabung juga mempengaruhi partisipan A dalam mengubah formula yang digunakan. Pada tahapan keterampilan proses, terjadi kesalahan strategis di mana partisipan A tidak dapat mengubah masalah untuk menemukan strategi penyelesaian lain yang tepat. Partisipan A mengabaikan bahwa luas permukaan tidak bisa digunakan untuk mencari isi dari sebuah bangun ruang dan sangat meyakini jawabannya benar karena sudah menggunakan formula dari bangun ruang tabung dan menghitung dengan teliti. Oleh karena itu, pada tahapan encoding partisipan A tidak bisa menemukan jawaban yang benar dari masalah ini. Setelah diberikan scaffolding partisipan A akhirnya bisa melihat hubungan antara ukuran dan bisa memikirkan strategi lain untuk mencari banyaknya gula aren yang dapat diisi ke dalam kaleng.

\section{Analisis Prosedur Newman pada Partisipan B}

Hasil jawaban partisipan B dalam menyelesaikan masalah no. 1 dapat dilihat pada

Gambar 4. 


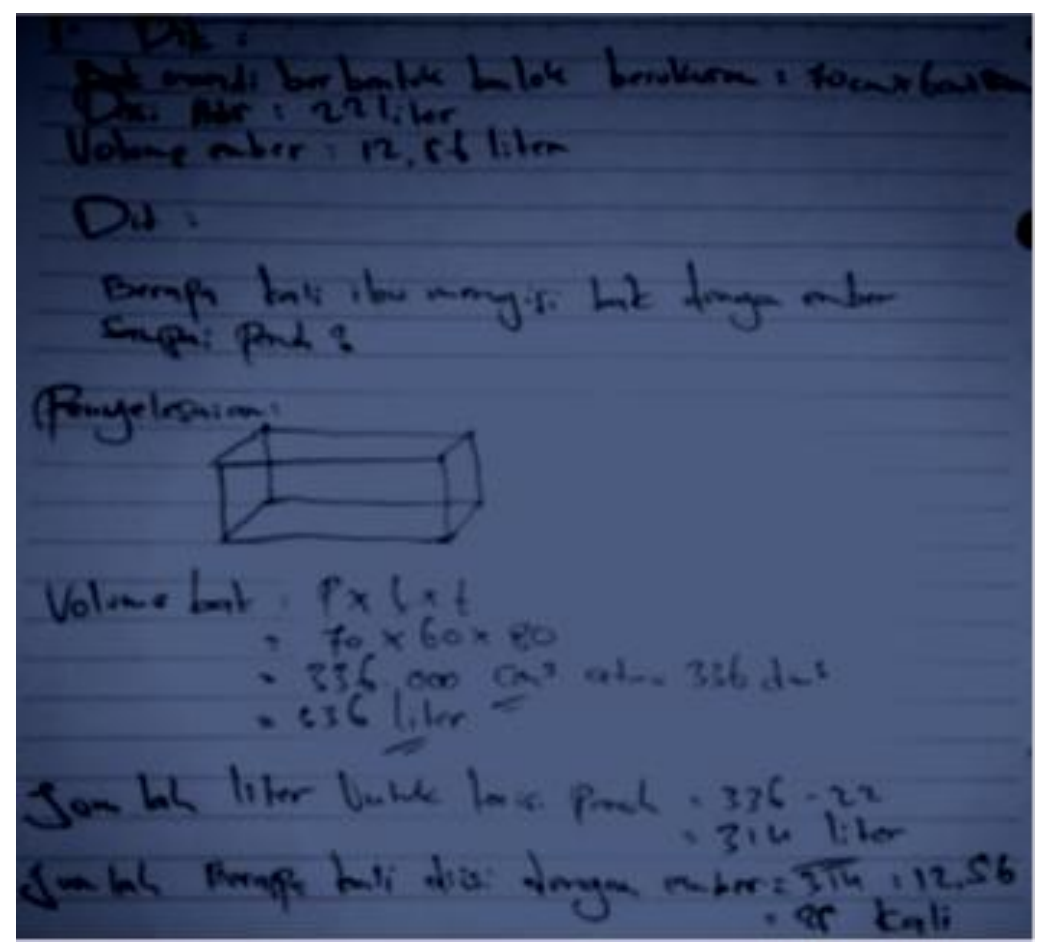

Gambar 4. Jawaban Partisipan B

Berdasarkan analisis hasil lembar kerja, partisipan $\mathrm{B}$ menjawab masalah pertama melalui tahapan berikut:

a. Menuliskan informasi pada masalah secara lengkap

b. Menggambar bangun ruang balok

c. Menuliskan rencana penyelesaian menggunakan volume balok d. Menyelesaikan masalah dengan mengikuti rencana penyelesaian dan membagi volume bak mandi dan volume ember.

Hal tersebut kemudian dikonfirmasi melalui proses wawancara yang dapat dilihat pada Tabel 6 .

\section{Tabel 6. Konfirmasi Jawaban Partisipan B pada Masalah Pertama}

\begin{tabular}{|c|c|}
\hline Peneliti & Partisipan B \\
\hline Silakan baca soalnya! & (membaca) \\
\hline Paham dengan maksud soalnya? & Paham, Bu. \\
\hline $\begin{array}{l}\text { Jelaskan proses } \\
\text { penyelesaiannya! }\end{array}$ & $\begin{array}{l}\text { Untuk soal nomor } 1 \text { karena yang dicari adalah berapa kali } \\
\text { mengisi bak mandi sampai penuh dengan ember. Pertama } \\
\text { dengan menentukan diketahui yaitu volume ember, } \\
\text { ukuran bak mandi dan volume bak mandi sebelum diisi } \\
\text { air. Mencari volume bak mandi dengan mengalikan semua } \\
\text { ukurannya sehingga memperoleh hasil } 336 \text { liter. Setelah } \\
\text { itu saya cari jumlah air yang diisi dengan mengurangkan } \\
\text { volume bak mandi } 336 \text { liter dengan yang sudah ada yaitu } \\
22 \text { liter. Setelah itu saya bagi dengan volume ember. } 314 \text { : } \\
12,56=25 \text {, jadi bak mandi diisi air dengan ember sampai } \\
\text { penuh sebanyak } 25 \text { kali. }\end{array}$ \\
\hline $\begin{array}{l}\text { Kenapa pada ukuran balok kamu } \\
\text { gunakan operasi perkalian? }\end{array}$ & $\begin{array}{l}\text { Itu ukuran bak, panjang, lebar dan tinggi dengan } \\
\text { mengikuti rumus volume balok yaitu } \mathrm{p} \times 1 \times \mathrm{t} \text {. }\end{array}$ \\
\hline $\begin{array}{l}\text { Kamu yakin dengan } \\
\text { jawabannya? }\end{array}$ & Yakin, Bu. Karena sudah menggunakan rumus yang ada. \\
\hline
\end{tabular}


Dari hasil lembar kerja terlihat bahwa partisipan B tidak melakukan kesalahan dalam proses penyelesaian masalah pertama. Setelah dikonfirmasi melalui wawancara, partisipan B meyakini bahwa jawaban yang diberikan benar dan memenuhi semua tahapan prosedur Newman. Partisipan B tidak melakukan kesalahan pada tahapan membaca, memahami, transformasi, keterampilan proses dan encoding. Partisipan B memahami maksud soal dan menggunakan formula dan perhitungan yang tepat sampai pada tahapan menentukan jawaban akhir.

Hasil jawaban partisipan B dalam menyelesaikan masalah no. 2 dapat dilihat pada

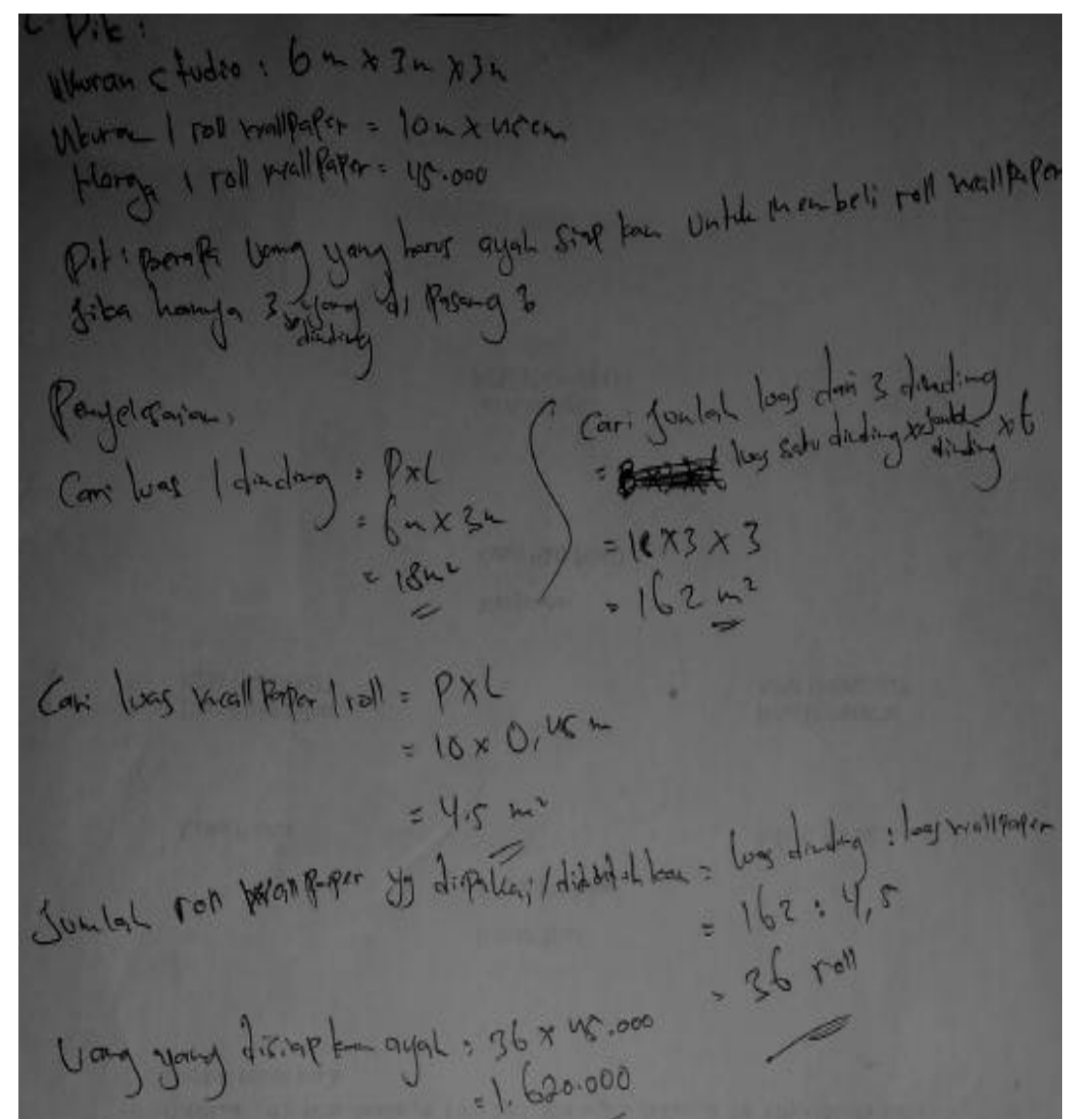

Gambar 5. Jawaban Partisipan B

Berdasarkan analisis hasil lembar kerja, partisipan B menjawab masalah kedua melalui tahapan berikut:

a. Menuliskan diketahui dan ditanyakan

b. Memahami setiap tahapan yang harus dilakukan untuk menyelesaikan masalah namun mengalami bingung konsep dalam menentukan luas 3 dinding. c. Luas 3 dinding diselesaikan dengan cara ( $\mathrm{p} \times 1) \times \mathrm{t} \times 3$ dinding.

d. Akibat kesalahan formula yang digunakan maka jawaban akhir yang ditemukan salah.

Hal tersebut kemudian dikonfirmasi melalui wawancara yang dapat dilihat pada Tabel 7. 
Tabel 7. Konfirmasi Jawaban Partisipan B pada Masalah Kedua Peneliti Partisipan B

\begin{tabular}{|c|c|}
\hline Peneliti & Partisipan B \\
\hline Silakan baca soalnya! & (membaca soal) \\
\hline Kamu paham dengan masalah ini? & Iya, paham Bu. \\
\hline $\begin{array}{l}\text { Bagaimana } \\
\text { menyelesaikannya? }\end{array}$ & $\begin{array}{l}\text { Pertama mencari luas } 3 \text { dinding, luas wallpaper, berapa } \\
\text { wallpaper yang digunakan dengan membagi luas } 3 \\
\text { dinding dan luas wallpaper kemudian mengalikan } \\
\text { dengan harga satu rol wallpaper. Luas satu dinding } 18 \\
\mathrm{~m}^{2} \text {. }\end{array}$ \\
\hline 18 hasil dari mana? & Dari $6 \times 3$ bu, dindingnya berbentuk persegi jadi p x 1 . \\
\hline
\end{tabular}

Di lembar kerja, luas 3 dinding Iya, Bu. jadi dari 18 tadi saya kalikan dengan 3 dinding $162 \mathrm{~m}^{2}$, bisa dijelaskan?

Kenapa dikali tinggi? kemudian saya kalikan lagi dengan tinggi dinding.

Ada informasi ukuran dinding pada soal, panjang $6 \mathrm{~m}$, lebar $4 \mathrm{~m}$ dan tinggi $3 \mathrm{~m} .3$ dinding ini memiliki tinggi yang berbeda.

Bisa tunjukkan studio yang kamu (Menggambar 3 dinding dengan posisi ukuran dinding di bayangkan seperti apa? tengah lebih tinggi dari dinding sebelah kiri dan kanan). Misal ini kotak (menunjukkan gambar), ini ada dinding pertama, dinding kedua dan dinding ketiga. Jadi studio ini dalam bentuk ruangan.

Apa sama antara wallpaper dan Tidak, karena untuk mencari luas wallpaper beda. dinding? Wallpaper tidak menggunakan tinggi, sedangkan dinding ada tinggi.

Alasannya? Ukuran dinding pada soal $\mathrm{p} \times 1 \times \mathrm{t}$.

Dinding dan wallpaper berbentuk apa?

Gambar satu dinding studio!

Dinding persegi, wallpaper persegi panjang

(Menggambar dinding dengan bentuk persegi tapi ukuran sisi 6 dan 3)

Dengan melihat gambar studio kamu, apa kaitan antara wallpaper Wallpaper adalah bangun datar jadi tidak ada tinggi, hanya panjang dan lebar. Sementara studio adalah bangun ruang yang memiliki panjang, lebar dan tinggi.

dan dinding studio?

ruangan sehingga memiliki tinggi.

Berdasarkan hasil wawancara dengan partisipan $\mathrm{B}$, ditemukan kesalahan yang muncul selain pada lembar kerja. Tidak terdapat kesalahan pada tahapan membaca dan pemahaman. Pada tahapan transformasi, partisipan B mengalami kesalahan matematis yaitu kelalaian dalam menggunakan formula dan bingung konsep. Ia mampu merencanakan cara mencari luas 1 dinding, tetapi tidak untuk 3 dinding. Kesalahan berlanjut pada tahapan keterampilan proses yaitu kesalahan logis. Partisipan B menyampaikan argumen yang salah untuk mencari luas 3 dinding menggunakan $\mathrm{p}$ x 1 x $\mathrm{t}$ x 3 , karena menganggap 3 dinding berada di dalam
Kesalahan logis tampak pada klasifikasi yang tidak sesuai, menganggap bahwa dinding berbentuk persegi, sedangkan wallpaper berbentuk persegi panjang. Partisipan B tidak bisa membedakan persegi dan persegi panjang. Karena partisipan B mengalami kesalahan pada tahapan sebelumnya, tahapan keterampilan proses dan encoding juga mengalami kesalahan terlihat dari jawaban yang diberikan salah.

Hasil jawaban partisipan B dalam menyelesaikan masalah no. 3 dapat dilihat pada

Gambar

6. 


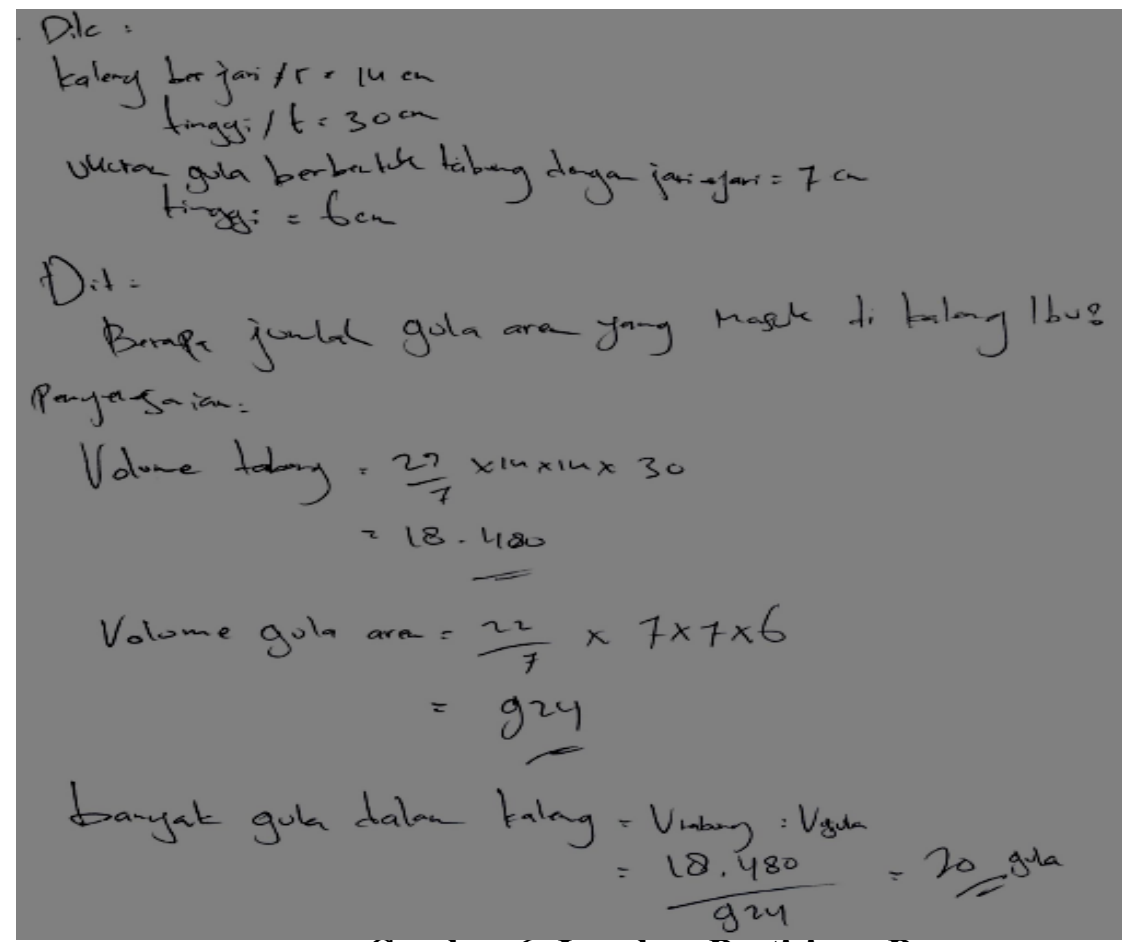

Gambar 6. Jawaban Partisipan B

Berdasarkan analisis hasil lembar kerja, partisipan B menjawab masalah kedua melalui tahapan berikut:

a. Menuliskan informasi diketahui dan ditanyakan.

b. Mencari volume kaleng dan gula aren dengan menggunakan volume tabung c. Menghitung banyak gula aren yang dapat diisi dengan membagi antara volume kaleng dan gula aren.

Hal tersebut kemudian dikonfirmasi melalui wawancara yang dapat dilihat pada Tabel

\section{8.}

\section{Tabel 8. Konfirmasi Jawaban Partisipan B pada Masalah Ketiga}

\begin{tabular}{|c|c|}
\hline Peneliti & Partisipan B \\
\hline Silakan baca masalah nomor 3 ! & (membaca) \\
\hline $\begin{array}{l}\text { Bagaimana cara kamu } \\
\text { menyelesaikan masalah ini? }\end{array}$ & $\begin{array}{l}\text { Pertama saya mencari volume kaleng, lalu mencari } \\
\text { volume gula aren. Setelah itu baru menentukan } \\
\text { banyaknya gula aren yang dapat diisi dengan cara } \\
\text { membagi sehingga dapat } 20 \text { gula aren. }\end{array}$ \\
\hline $\begin{array}{l}\text { Mengapa kamu menggunakan } \\
\text { rumus volume? }\end{array}$ & $\begin{array}{l}\text { Menurut saya, cari dulu berapa luas, eh ukuran dari gula } \\
\text { aren untuk bisa masuk ke dalam kaleng }\end{array}$ \\
\hline Luas atau volume? & $\begin{array}{l}\text { Maksud saya volume. Volume itu sama seperti luas. } \\
\text { Kalau istilahnya tidak sama, tapi saya anggap sama. }\end{array}$ \\
\hline Mengapa? & Karena ukuran dari keseluruhan tabung itu sama \\
\hline $\begin{array}{l}\text { Gambarkan tabung, kemudian } \\
\text { tunjukkan yang mana luas dan } \\
\text { volume! }\end{array}$ & $\begin{array}{l}\text { Volume itu yang ada di dalam, saya menganggap sama } \\
\text { karena luas itu berapa yang dapat diisi. Luas hanya di } \\
\text { bangun datar dan volume di bangun ruang }\end{array}$ \\
\hline $\begin{array}{l}\text { Jadi, kamu sudah yakin dengan } \\
\text { jawabanmu? }\end{array}$ & Sudah, 20. \\
\hline $\begin{array}{l}\text { Bisa membandingkan ukuran } \\
\text { antara kaleng dan gula aren? }\end{array}$ & $\begin{array}{l}\text { Bisa. Lebih lebar jari-jari tabung daripada gula aren, } \\
\text { lebih tinggi kaleng dari gula aren }\end{array}$ \\
\hline Dengan 20 gula aren, pas atau & Pas, Bu. Soalnya disusun ke atas ada dua bagian. Seperti \\
\hline
\end{tabular}


lebih di dalam kaleng?

Gula aren dalam keadaan utuh?

Apa gula arennya cukup atau lebih jika memperhatikan ukurannya?

Jadi kenapa menggunakan rumus? ini (menunjukkan posisi gula aren bersebelahan) Iya, Bu.

Menurut saya, realitanya lebih. Dilihat dari tinggi kaleng dan gula aren logikanya ke atas 5 karena dua berdampingan sehingga 10 .

Saya melihat dari ukurannya ada jari-jari dan itu bangun ruang tabung sehingga harus menggunakan rumus untuk menyelesaikannya.
Partisipan B dapat memahami maksud dari soal, akan tetapi rencana penyelesaian yang ia buat keliru. Pada tahapan memahami, partisipan B mengalami kesalahan matematis yaitu kondisi matematis. Ia mengetahui kondisi matematis pada masalah tapi mengabaikannya dengan alasan jika masalah terkait bangun ruang kemudian memiliki ukuran, misalnya jari-jari maka rencana penyelesaiannya adalah menggunakan rumus. Pada tahapan transformasi terjadi jenis kesalahan matematis yaitu bingung konsep. Partisipan B tidak dapat membedakan antara volume dan luas permukaan bangun ruang, ia menganggap bahwa luas hanya ada pada bangun datar, hal ini yang menjadi dasar pengambilan keputusan dalam memilih rencana penyelesaian. Pada tahapan keterampilan proses, jenis kesalahan yang muncul adalah kesalahan logis yaitu argumen yang disampaikan salah dan kesalahan strategis. Karena argumen partisipan B yang memandang bahwa semua masalah bangun ruang harus diselesaikan dengan rumus volume, mengakibatkan ia tidak dapat mengubah strategi penyelesaian. Tahapan encoding juga tidak dapat tercapai dengan benar karena partisipan B sudah mengalami kesalahan pada tahap sebelumnya. Melalui proses scaffolding partisipan A dapat meyakini bahwa jawaban masalah ketiga dapat diselesaikan meskipun tanpa menggunakan rumus.

\section{Pembahasan}

Berdasarkan hasil penelitian yang dipaparkan sebelumnya, dapat terlihat bahwa pada empat tahapan prosedur Newman terjadi kesalahan matematis.
Hanya satu tahapan pada prosedur Newman yang tidak mengalami kesalahan, yaitu tahapan membaca. Kesalahan matematis yang terjadi pada klasifikasi matematis, logis dan strategis. Namun, klasifikasi psikologis tidak terjadi pada semua tahapan. Kemudian, sebagai temuan baru dalam penelitian ini, kesalahan matematis yang dialami oleh partisipan pada tahapan prosedur Newman dapat menyebabkan pada tahapan selanjutnya. Artinya, kesalahan matematis dapat saling mempengaruhi. Lebih lanjut akan dibahas terkait kondisi-kondisi yang terjadi penelitian.

Pada tahapan pemahaman, kedua partisipan mengalami kesalahan matematis yaitu pada klasifikasi bingung konsep dalam membedakan antara volume dan luas permukaan bangun ruang, selain itu bingung konsep juga tampak pada mengklasifikasikan bangun datar. Hal ini sesuai dengan hasil penelitian bahwa mahasiswa tidak memiliki konsep yang kuat dan stabil bahkan pada level kognitif rendah terkait bentuk dan sifat geometri dasar atau meskipun jika mereka memilikinya, sebagian adalah konsep yang salah (Zilkova et al., 2015).

Pada tahapan transformasi, kedua partisipan mengalami kesalahan matematis, yaitu pada klasifikasi bingung konsep sehingga menyebabkan kelalaian menggunakan formula dalam menyusun rencana penyelesaian. Salah satu kesulitan siswa adalah kurang mampu mengaplikasikan konsep pada konteks yang sesuai dan kesulitan dalam melakukan manipulasi atau menyusun formula penyelesaian masalah matematis yang abstrak (Nurhikmayati, 2017). Siswa menggunakan konsep yang salah, sehingga 
mereka tidak mengerjakan langkah selanjutnya dengan benar. Sebagian besar kesalahan pada tahapan transformasi terjadi karena konsep matematika yang keliru (Riastuti et al., 2017).

Pada tahapan keterampilan proses, kedua partisipan mengalami kesalahan logis, yaitu pada klasifikasi menyampaikan argumen yang salah, sementara satu partisipan mengalami klasifikasi kesalahan logis lainnya yaitu klasifikasi yang tidak sesuai. Argumen yang disampaikan partisipan terkait dinding berdasarkan bayangan bahwa dinding memiliki tinggi. Pengalaman intuitif mahasiswa yang tidak dapat dipercaya dapat menghambat proses kognitif dalam menyelesaikan masalah (Nanna \& Pratiwi, 2020). Partisipan lainnya tidak bisa mengklasifikasikan persegi dan persegi panjang dengan benar. Salah satu alasan mengapa beberapa siswa gagal dalam geometri dasar karena mereka tahu sifat dari bentuknya, tetapi melupakan beberapa bagian definisi (Marchis, 2012). Kesalahan logis tersebut mengakibatkan munculnya kesalahan strategis kedua partisipan pada klasifikasi tidak dapat mengubah masalah untuk menemukan strategi penyelesaian yang lain. Kesalahan strategi dapat terjadi karena mahasiswa memilih cara mengerjakan yang tidak tepat (Imswatama \& Muhassanah, 2016). Hasil penelitian lainnya membuktikan siswa gagal mengevaluasi, menghubungkan, menafsirkan, menjelaskan dan menghasilkan strategi yang sesuai dalam menjawab masalah. Siswa teridentifikasi tidak memiliki kemampuan dalam menghubungkan pengalaman sebelumnya dengan informasi baru yang mereka dapatkan untuk memecahkan masalah (Abu \& Abdullah, 2017).

Pada tahapan encoding, kedua partisipan mengalami kesalahan yang disebabkan kesalahan yang muncul pada tahapan-tahapan sebelumnya, baik pada tahapan memahami, transformasi dan keterampilan proses. Hasil penelitian lainnya menunjukkan bahwa masih banyak siswa yang melakukan kesalahan pada tahap encoding bahkan sebagian besar dilakukan siswa dengan kemampuan tinggi (Santoso et al., 2017). Kesalahan matematis, kesalahan logis dan kesalahan strategis mengakibatkan partisipan tidak mampu menemukan jawaban yang benar pada tahapan encoding. Pencapaian yang rendah dalam menyelesaikan masalah dapat dikaitkan dengan ketidakmampuan dalam memahami dan memilih rencana dan strategi penyelesaian masalah yang efektif (Avcu \& Avcu, 2010).

Kesalahan matematis yang terjadi pada empat tahapan prosedur Newman dalam pemahaman, transformasi, keterampilan proses dan encoding yaitu kesalahan matematis yang terjadi pada klasifikasi matematis, logis dan strategis. Kesalahan yang termasuk pada klasifikasi matematis, yaitu bingung konsep dan kelalaian dalam penggunaan formula. Kesalahan yang termasuk pada klasifikasi logis, yaitu argumen yang digunakan dalam menyelesaikan masalah geometri salah. Selain itu, partisipan tidak mampu mengatur ulang konsep terhadap masalah yang diberikan. Selanjutnya, kesalahan yang termasuk pada klasifikasi strategi, yaitu partisipan tidak dapat mengubah masalah untuk dikaitkan dengan informasi yang sudah diberikan dan yang dimiliki. Partisipan tidak dapat menghubungkan antara apa yang sedang dihadapi yang berupa soal dengan informasi yang sudah dimiliki. Hal ini sesuai dengan (Pratiwi et al., 2020) yang menyatakan bahwa pergeseran antara hasil kerja mahasiswa dalam bentuk tulisan atau gambar dan penggunaan segala sesuatu yang diketahui akan menyebabkan konflik commognitive, yaitu konflik yang terjadi antara komunikasi dan kognisi mahasiswa. Namun, klasifikasi psikologis tidak terjadi pada semua tahapan. Klasifikasi psikologis tidak terjadi karena partisipan yang terlibat dalam penelitian sudah menempuh mata kuliah Geometri. Sehingga, partisipan sudah siap dalam menyelesaikan masalah geometri, khususnya materi bangun ruang.

Kesalahan yang muncul pada tahapan pemahaman dapat mempengaruhi kesalahan pada tahapan-tahapan selanjutnya. Seperti yang terjadi pada tahapan pemahaman, yaitu kesalahan matematis. Kesalahan matematis dapat menyebabkan kesalahan logis pada tahapan 
berikutnya. Selain itu, pada tahapan transformasi, terjadi kesalahan logis. Kesalahan logis tersebut menyebabkan kesalahan strategis pada keterampilan proses dan encoding.

\section{Simpulan dan Saran Simpulan}

Hasil pembahasan menunjukkan bahwa dalam penyelesaian masalah geometri terdapat kesalahan matematis yang terjadi dalam empat tahapan prosedur Newman, yaitu pada klasifikasi matematis, logis dan strategi. Tahapan membaca pada prosedur Newman tidak mengalami kesalahan pada kedua partisipan. Kemudian, pada tahapan terakhir, yaitu encoding, kesalahan terjadi karena jawaban yang tidak benar. Kondisi tersebut disebabkan kesalahan pada tahapan-tahapan sebelumnya.

Selanjutnya, sebagai temuan baru dalam penelitian ini, terlihat pengaruh kesalahan pada tahapan prosedur Newman yang menyebabkan kesalahan pada tahapan selanjutnya. Kesalahan yang dimaksud adalah kesalahan pada klasifikasi matematis yang mengakibatkan kesalahan pada klasifikasi logis dan kesalahan pada klasifikasi logis yang menyebabkan kesalahan pada klasifikasi strategi.

\section{Saran}

1. Pada empat tahapan prosedur Newman terjadi kesalahan matematis, yaitu pemahaman, transformasi, keterampilan proses dan encoding. Oleh karena itu, perlu melakukan desain soal pada mata kuliah Geometri, khususnya materi bangun ruang, yang melibatkan prosedur Newman sehingga tidak ada lagi kesalahan yang muncul dalam semua tahapan.

2. Kesalahan matematis yang terjadi pada tahapan prosedur Newman dapat menyebabkan kesalahan matematis pada tahapan selanjutnya. Oleh karena itu, dapat dilakukan analisis terkait sumber utama kesalahan matematis yang paling mempengaruhi kesalahan matematis lainnya dalam menyelesaikan masalah geometri.

\section{Daftar Pustaka}

Abu, M. S., \& Abdullah, A. H. (2017). Newman Error Analysis on Evaluating and Creating Thinking Skills. December.

Aslan-tutak, F., \& Adams, T. L. (2015). A Study of Geometry Content Knowledge of Elementary Preservice Teachers. International Electronic Journal of Elementary Education, 7(510), 301-318.

Avcu, S., \& Avcu, R. (2010). Pre-service elementary mathematics teacher's use of strategies in mathematical problem solving. Procedia - Social and Behavioral Sciences, 9, 1282-1286. https://doi.org/10.1016/j.sbspro.2010. 12.321

Browning, C., Edson, A. J., Kimani, P. M., \& Aslan-Tutak, F. (2014). Mathematical content knowledge for teaching elementary mathematics: A focus on geometry and measurement. Mathematics Enthusiast.

Haryanti, M. D., Herman, T., \& Prabawanto, S. (2019). Analysis of students' error in solving mathematical word problems in geometry. Journal of Physics: Conference Series, 1157(4). https://doi.org/10.1088/17426596/1157/4/042084

Hourigan, M., \& Leavy, A. M. (2017). Preservice Primary Teachers' Geometric Thinking: Is Pre-Tertiary Mathematics Education Building Sufficiently Strong Foundations? Teacher Educator, 52(4), 346-364. https://doi.org/10.1080/08878730.201 7.1349226

Huberman, A., \& Miles, M. (2012). The Qualitative Researcher's Companion. In The Qualitative Researcher's Companion. https://doi.org/10.4135/978141298627 4 
Imswatama, A., \& Muhassanah, N. (2016). Analisis Kesalahan Mahasiswa Dalam Menyelesaikan Soal Geometri Analitik Bidang Materi Garis Dan Lingkaran. Suska Journal of Mathematics Education, 2(1), 1. https://doi.org/10.24014/sjme.v2i1.13 68

Jha, S. K. (2012). Mathematics Performance of Primary School Students in Assam ( India ): An Analysis Using Newman Procedure. II(I), 17-21.

Jones, K. (2000). Teacher knowledge and professional development in geometry. Proceedings of the British Society for Research into Learning Mathematics, 20, (3), 109-114.

Marchis, I. (2012). Precervice Primary School Teachers' Elementary Geometry Knowledge. Acta Didactica Napocensia, 5(2).

Nanna, A. W. I., \& Pratiwi, E. (2020). Students, Cognitive Barrier in Problem Solving: Picture -based Problem-solving. Al-Jabar: Jurnal Pendidikan Matematika, 11(1), 72-82. https://doi.org/doi.org/10.24042/ajpm. v11i1.5652

National Council of Teachers of Mathematics. (2008). Choice Reviews Online.

https://doi.org/10.5860/choice.452738

Newman, M. A. (1977). An analysis of sixfll-grade pupils' errors on written mathematicaI tasks. Research in Mathematics Education in Australia.

Nurhikmayati, I. (2017). Kesulitan Siswa Berpikir Abstrak Matematika dalam Pembelajaran Problem Posing Berkelompok. 2(2), 159-176.

Özerem, A. (2012). Misconceptions In Geometry And Suggested Solutions For Seventh Grade Students.
International Conference on New Horizons in Education, 55, 720-729. https://doi.org/10.1016/j.sbspro.2012. 09.557

Ozkan, M., \& Bal, A. P. (2017). Analysis of the Misconceptions of 7th Grade Students on Polygons and Specific Quadrilaterals. January, 161-182. https://doi.org/10.14689/ejer.2017.67. 10

Peng, A., \& Luo, Z. (2009). A Framework for Examining Mathematics Teacher Knowledge as Used in Error Analysis. 3(1997).

Prakitipong, N., \& Nakamura, S. (2006). Analysis of mathematics performance of grade five students in Thailand using Newman procedure. Journal of International Cooperation ..., 9(1), 111-122. http://home.hiroshimau.ac.jp/cice/wp-

content/uploads/publications/Journal9 -1/9-1-9.pdf

Pratiwi, E., Nusantara, T., Susiswo, S., \& Muksar, M. (2020). Textual and contextual commognitive conflict students in solving an improper fraction. 8(June), 731-742.

Riastuti, N., Mardiyana, M., \& Pramudya, I. (2017). Students' Errors in Geometry Viewed from Spatial Intelligence. International Conference on Mathematics and Science Education (ICMScE). https://doi.org/10.1088/17426596/895/1/012029

Rohmah, M., \& Sutiarso, S. (2018). Analysis problem solving in mathematical using theory Newman. Eurasia Journal of Mathematics, Science and Technology Education, 14(2), 671-681. https://doi.org/10.12973/ejmste/80630

Safriani, W., Munzir, S., Duskri, M., \& Maulidi, I. (2019). Analysis of Students' Errors on the Fraction 
Calculation Operations Problem. AlJabar: Jurnal Pendidikan Matematika, 10(02), 307-318.

Salleh, Z., Saad, N. M., Arshad, M. N., Yunus, H., \& Zakaria, E. (2013). Analisis jenis kesilapan dalam operasi penambahan dan penolakan pecahan. Jurnal Pendidikan Matematik.

Santos-Trigo, M. (2020). Problem-Solving in Mathematics Education. Lerman S. (Eds) Encyclopedia of Mathematics Education. Springer, Cham.

Santoso, D. A., A, F., \& Ulum, B. (2017). Error Analysis Of Students Working About Word Problem Of Linear Program With NEA Procedure. International Conference on Mathematics: Education, Theory and Application.
Sulistyorini, Y. (2018). Error Analysis in Solving Geometry Problem on Pseudo-Thinking's Students. 160(Incomed 2017), 103-107. https://doi.org/10.2991/incomed17.2018.22

White, A. L. (2005). Active mathematics in classrooms: Finding out why children make mistakes - and then doing something to help them. Journal of Science and Mathematics Education in Southeast Asia, 15(4), 15-19. http://citeseerx.ist.psu.edu/viewdoc/do wnload?doi=10.1.1.472.9065\&rep=re p1\&type $=$ pdf

Zilkova, K., Gunčaga, J., \& Kopáčová, J. (2015). (mis)conceptions about geometric shapes in pre- service primary teachers. $8(01)$. 